\title{
Staphylococcus epidermidis strains isolated from breast milk of women suffering infectious mastitis: potential virulence traits and resistance to antibiotics
}

\author{
Susana Delgado1, Rebeca Arroyo1, Esther Jiménez ${ }^{1}$, Maria L Marín ${ }^{1}$, Rosa del \\ Campo $^{2}$, Leonides Fernández ${ }^{1}$ and Juan M Rodríguez*1
}

Address: ${ }^{1}$ Dpt. Nutrición, Bromatología y Tecnología de los Alimentos. Universidad Complutense de Madrid, 28040 Madrid, Spain and ${ }^{2}$ Servicio de Microbiología, Hospital Ramón y Cajal, 28034 Madrid, Spain

Email: Susana Delgado - sdelgado@vet.ucm.es; Rebeca Arroyo - rebecaa@vet.ucm.es; Esther Jiménez - esjimene@vet.ucm.es; Maria L Marín - mlmarin@vet.ucm.es; Rosa del Campo - rosacampo@yahoo.com; Leonides Fernández - leonides@vet.ucm.es; Juan M Rodríguez* - jmrodrig@vet.ucm.es

* Corresponding author

Published: 7 May 2009

BMC Microbiology 2009, 9:82 doi:10.1/86/147|-2180-9-82
Received: 5 December 2008

Accepted: 7 May 2009

This article is available from: http://www.biomedcentral.com/I47I-2/80/9/82

(c) 2009 Delgado et al; licensee BioMed Central Ltd.

This is an Open Access article distributed under the terms of the Creative Commons Attribution License (http://creativecommons.org/licenses/by/2.0), which permits unrestricted use, distribution, and reproduction in any medium, provided the original work is properly cited.

\begin{abstract}
Background: Although Staphylococcus aureus is considered the main etiological agent of infectious mastitis, recent studies have suggested that coagulase-negative staphylococci (CNS) may also play an important role in such infections. The aims of this work were to isolate staphylococci from milk of women with lactational mastitis, to select and characterize the CNS isolates, and to compare such properties with those displayed by CNS strains isolated from milk of healthy women.

Results: The milk of 30 women was collected and bacterial growth was noted in 27 of them, of which Staphylococcus epidermidis was isolated from 26 patients and S. aureus from 8. Among the 270 staphylococcal isolates recovered from milk of women with mastitis, 200 were identified as Staphylococcus epidermidis by phenotypic assays, species-specific PCR and PCR sequencing. They were typified by pulsed field gel electrophoresis (PFGE) genotyping. The PFGE profiles of the S. epidermidis strains were compared with those of 105 isolates from milk of healthy women. A representative of the 76 different PFGE profiles was selected to study the incidence of virulence factors and antibiotic resistance. The number of strains that contained the biofilm-related icaD gene and that showed resistance to oxacillin, erythromycin, clindamycin and mupirocin was significantly higher among the strains isolated from mastitic milk.
\end{abstract}

Conclusion: S. epidermidis may be a frequent but largely underrated cause of infectious mastitis in lactating women. The resistance to diverse antibiotics and a higher ability to form biofilms found among the strains isolated from milk of women suffering mastitis may explain the chronic and/or recurrent nature of this infectious condition.

\section{Background}

Mastitis is a common condition during lactation and its incidence oscillates between 5 and $33 \%$ of the lactating mothers $[1,2]$. The number of non-infectious mastitis that become an infectious disease is usually so high that some authors define the term "mastitis" as an infectious process 
of the mammary gland characterized by a variety of local and systemic symptoms [3]. However, the number of studies dealing with the microbiological aspects of human mastitis is low and the role of specific agents has yet to be described. In fact, published articles on the bacteria causing this condition are scarce and most are, at least, 10 years old [2].

Traditionally, Staphylococcus aureus has been considered the most common etiological agent although, unfortunately, the cases in which microbiological analyses are performed are exceptional. However, treatments with antibiotic or antifungal drugs are usually prescribed without knowing the etiology or the antibiotic susceptibility of the microorganism involved. This practice may lead to a worsening of the symptoms since strains that cause mastitis may exhibit multirresistance to drugs and/or form biofilms. Therefore, a better knowledge of the main features of the bacterial species involved in the mastitic process would represent a great advance for the design of new strategies for the prevention and/or treatment of this condition.

In a previous work, we investigated the microbial diversity of breast milk in 20 women with lactational mastitis by culture-dependent and -independent techniques [4], and observed that staphylococci, mainly Staphylococcus epidermidis, seem to be the major microorganisms present in breast milk of women with infectious mastitis. In recent years $S$. epidermidis has become increasingly recognized as opportunistic pathogen [5,6]. Parallel, several genetic determinants involved in mechanisms of adhesion and biofilm formation have been described in this species $[7,8]$ while its rate of resistance to several antibiotics has increased during the last years [9-11].

In this context, the objective of the present study was to evaluate the presence of $S$. epidermidis in breast milk of women with infectious mastitis, to characterize the isolates and to compare their properties with those of strains isolated from milk of healthy women.

\section{Results}

Bacterial counts and identification of staphylococci in milk Presence of staphylococci was observed in 27 of the 30 samples provided by women with lactational mastitis. In these samples, counts in Baird Parker (BP) agar plates ranged between 4.0 and $6.0 \log _{10}$ cfu $\mathrm{mL}^{-1}$ (Table 1). A total of 270 isolates were obtained from the BP plates (10 from each woman) and all of them were lysozyme-resistant, lysostaphin-sensitive, catalase-positive, Gram-positive cocci. Among these presumptive staphylococcal isolates, 200 were identified as S. epidermidis on the basis of biochemical tests and species-specific PCR assays. This species was present in 26 milk samples. Only 35 staphylo- coccal isolates belonged to the species $S$. aureus and they were obtained from milk of eight women. PCR sequencing of a $16 \mathrm{~S}$ rDNA fragment confirmed the results. The remaining 35 isolates that gave no amplification with the multiplex PCR were further identified by $16 \mathrm{~S}$ rDNA PCR sequencing as Staphylococcus pasteuri $(\mathrm{n}=16)$, Staphylococcus warneri $(\mathrm{n}=11)$ and Staphylococcus hominis $(\mathrm{n}=8)$ (Table 1). The partial 16S rDNA sequences obtained from single isolates belonging to the species Staphylococcus aureus and Staphylococcus epidermidis were deposited in the EMBL nucleotide sequence database under accession numbers [EMBL: $\underline{\text { AM697666] }}$ and [EMBL: AM697667], respectively. Then, our attention was focused on the $S$. epidermidis isolates.

\section{Genotyping of the S. epidermidis isolates by PFGE profiling}

The 200 isolates of $S$. epidermidis recovered in this study were subjected to PFGE genotyping together with 105 isolates previously obtained from breast milk of 12 healthy women (Table 1). The analysis of the fingerprints obtained revealed the existence of 40 different pulsotypes among the isolates from women with mastitis and 36 among healthy women. Comparison of these genotypes showed that most of the strains grouped together depending on their origin in two different clusters, one containing most of the strains obtained from mastitic milk while the second contained most of the strains isolated from milk of healthy women (Figure 1).

\section{Detection of virulence determinants among the S. epidermidis strains}

The 76 different $S$. epidermidis strains (40 from milk of women with mastitis and 36 strains from that of healthy women) were selected to study the presence of potential virulence traits. Hemolytic activity could not be detected or was very weak among all the assayed strains. In relation to adhesion-related genes, the multiplex PCR assay revealed the presence of the genes embp and atlE in all the strains. The fbe gene was detected in $65 \%$ of the strains from mastitis and in $75 \%$ of those isolated from healthy women $(\mathrm{P}=0,3434)$. In contrast, the ica $\mathrm{D}$ gene was more prevalent among strains from mastitis cases $(33 \%)$ than in those from healthy women $(11 \%)(\mathrm{P}=0,0255)$ (Figure 1). A good correlation was observed between the presence of biofilm-related ica operon and the results obtained using the CRA assay, which determines potential for slime production, and all the strains that amplified for the gene gave also positive results by the phenotypic assay.

\section{Determination of MIC's to several antibiotics}

Determination of MIC's to 21 antibiotics or antibiotics mixtures in the 76 S. epidermidis strains revealed that all of them were susceptible to the lower concentration of nitrofurantoin $\left(32 \mu \mathrm{g} \mathrm{mL}^{-1}\right)$ and rifampin $\left(1 \mu \mathrm{g} \mathrm{mL}^{-1}\right)$ while the 
Table I: Samples and isolates used in this study

\begin{tabular}{|c|c|c|c|c|}
\hline Milk sample & $\begin{array}{l}\text { Staphylococcal concentration }\left(\log _{10} \text { cfu } \mathrm{mL}^{-1} \pm\right. \\
\text { SD; } \mathrm{n}=3)\end{array}$ & $\begin{array}{l}\text { Identified species } \\
\text { (number of isolates) }\end{array}$ & $\begin{array}{c}\text { Number of PFGE profiles ( } S . \\
\text { epidermidis) }\end{array}$ & $\begin{array}{l}\text { Characterized S. epidermidis } \\
\text { strains }\end{array}$ \\
\hline \multicolumn{5}{|c|}{ A. Women with mastitis } \\
\hline I & $5.28 \pm 0.05$ & S. epidermidis (5) S. aureus (5) & 1 & $\mathrm{C} 213$ \\
\hline 2 & $4.78 \pm 0.32$ & S. epidermidis (I0) & 3 & $\begin{array}{l}\text { CJBPI } \\
\text { CJBP2 } \\
\text { CJBP3 }\end{array}$ \\
\hline 3 & Nd & - & - & - \\
\hline 4 & Nd & - & - & - \\
\hline 5 & $4.91 \pm 0.29$ & $\begin{array}{l}\text { S. epidermidis (8) } \\
\text { S. aureus (I) } \\
\text { S. pasteuri (I) }\end{array}$ & I & B \\
\hline 6 & $4.41 \pm 0.17$ & S. epidermidis (7) S. hominis (3) & 1 & $\mathrm{~K}$ \\
\hline 7 & $4.04 \pm 0.09$ & $\begin{array}{l}\text { S. epidermidis }(7) \\
\text { S. aureus ( } 3)\end{array}$ & 2 & $\begin{array}{l}\text { Cj9 } \\
\text { CjII }\end{array}$ \\
\hline 8 & $4.91 \pm 0.50$ & S. epidermidis (I0) & 3 & $\begin{array}{l}\text { SILDCI2 } \\
\text { SILDCI3 } \\
\text { SILDCI8 }\end{array}$ \\
\hline 9 & $4.72 \pm 0.44$ & $\begin{array}{l}\text { S. epidermidis (2) } \\
\text { S. pasteuri (4) } \\
\text { S. hominis (4) }\end{array}$ & 1 & $\mathrm{FI} 2$ \\
\hline 10 & $4.23 \pm 0.47$ & S. epidermidis (10) & 1 & DC2Lae \\
\hline 11 & $4.38 \pm 0.22$ & S. epidermidis (6) S. aureus (4) & 1 & BICD2 \\
\hline 12 & $4.08 \pm 0.51$ & S. epidermidis $(10)$ & I & DD2Laa \\
\hline 13 & $\mathrm{Nd}$ & - & - & - \\
\hline 14 & $4.25 \pm 0.08$ & $\begin{array}{l}\text { S. epidermidis (5) } \\
\text { S. aureus (5) }\end{array}$ & 1 & PLD2। \\
\hline 15 & $4.41 \pm 0.15$ & S. epidermidis $(10)$ & 1 & P2LDI \\
\hline 16 & $4.51 \pm 0.12$ & $\begin{array}{l}\text { S. epidermidis }(6) \\
\text { S. warneri (4) }\end{array}$ & 1 & MI2I \\
\hline 17 & $4.52 \pm 0.04$ & $\begin{array}{l}\text { S. epidermidis (7) } \\
\text { S. pasteuri (3) }\end{array}$ & 1 & DF2Lab \\
\hline 18 & $4.80 \pm 0.53$ & $\begin{array}{l}\text { S. epidermidis (8) } \\
\text { S. warneri (2) }\end{array}$ & 1 & VILDI \\
\hline 19 & $5.68 \pm 0.22$ & $\begin{array}{l}\text { S. epidermidis ( }(8) \\
\text { S. pasteuri ( } 2)\end{array}$ & I & DH3LIk \\
\hline 20 & $4.48 \pm 0.33$ & $\begin{array}{l}\text { S. epidermidis (9) } \\
\text { S. hominis (I) }\end{array}$ & 2 & $\begin{array}{l}\text { DG2ñ } \\
\text { DG2s }\end{array}$ \\
\hline 21 & $4.04 \pm 0.12$ & S. epidermidis (5) S. warneri (5) & 1 & YGLI4 \\
\hline 22 & $4.17 \pm 0.06$ & S. epidermidis (7) S. aureus (3) & 1 & ASLI3 \\
\hline 23 & $5.44 \pm 0.09$ & S. epidermidis (10) & 3 & $\begin{array}{l}\text { ASLDI } \\
\text { ASLD2 } \\
\text { ASLD3 }\end{array}$ \\
\hline
\end{tabular}


Table I: Samples and isolates used in this study (Continued)

\begin{tabular}{|c|c|c|c|c|}
\hline 24 & $4.15 \pm 0.45$ & $\begin{array}{l}\text { S. epidermidis (7) } \\
\text { S. pasteuri (3) }\end{array}$ & $\mathrm{I}$ & ARLII \\
\hline 25 & $4.64 \pm 0.14$ & S. epidermidis (10) & 4 & $\begin{array}{l}\text { Z2LDCII } \\
\text { Z2LDCI } 2 \\
\text { Z2LDCI } 14 \\
\text { Z2LDCI }\end{array}$ \\
\hline 26 & $4.02 \pm 0.22$ & S. epidermidis ( 10$)$ & I & AQLI2 \\
\hline 27 & $4.05 \pm 0.07$ & $\begin{array}{l}\text { S. epidermidis (6) } \\
\text { S. aureus (4) }\end{array}$ & I & AQLD3 \\
\hline 28 & $4.04 \pm 0.03$ & S. aureus (10) & - & - \\
\hline 29 & $4.09 \pm 0.09$ & $\begin{array}{l}\text { S. epidermidis (7) } \\
\text { S. pasteuri (3) }\end{array}$ & I & AEAI \\
\hline 30 & $4.05 \pm 0.24$ & S. epidermidis (I0) & 4 & $\begin{array}{l}\text { YLICI3 } \\
\text { YLICI } 4 \\
\text { YLICI } 6 \\
\text { YLICI } 7\end{array}$ \\
\hline
\end{tabular}

\section{B. Healthy women}

\begin{tabular}{|c|c|c|c|c|}
\hline 1 & $2.91 \pm 0.27$ & $\begin{array}{l}\text { S. epidermidis (5) } \\
\text { S. aureus (4) } \\
\text { S. lugdunensis (I) }\end{array}$ & 5 & $\begin{array}{l}\text { LCOI6 } \\
\text { LCOI7 } \\
\text { LCOI9 } \\
\text { LC044 } \\
\text { LC047 }\end{array}$ \\
\hline 2 & $2.41 \pm 0.09$ & S. epidermidis (I0) & 3 & $\begin{array}{l}\text { LEOIO } \\
\text { LEOII } \\
\text { LE035 }\end{array}$ \\
\hline 3 & $2.04 \pm 0.11$ & S. epidermidis (I0) & 5 & $\begin{array}{l}\text { LG0005 } \\
\text { LG006 } \\
\text { LG5021 } \\
\text { LG5022 } \\
\text { LG5023 }\end{array}$ \\
\hline 4 & $1.91 \pm 0.12$ & S. epidermidis (10) & 2 & $\begin{array}{l}\text { LP22 } \\
\text { LP223 }\end{array}$ \\
\hline 5 & $2.02 \pm 0.29$ & $\begin{array}{l}\text { S. epidermidis (8) } \\
\text { S. hominis (2) }\end{array}$ & 3 & $\begin{array}{l}\text { LV22I } \\
\text { LV222 } \\
\text { LV521 }\end{array}$ \\
\hline 6 & $2.93 \pm 0.21$ & S. epidermidis (10) & 3 & $\begin{array}{l}\text { LX5RB3 } \\
\text { LX5RB4 } \\
\text { LX508I }\end{array}$ \\
\hline 7 & $2.38 \pm 0.14$ & $\begin{array}{l}\text { S. epidermidis (4) } \\
\text { S. aureus (4) } \\
\text { S. hominis (2) }\end{array}$ & 3 & $\begin{array}{l}\text { LO508I } \\
\text { LO5082 } \\
\text { LO5RBI }\end{array}$ \\
\hline 8 & $2.58 \pm 0.31$ & S. epidermidis (I0) & 3 & $\begin{array}{l}\text { LCC508I } \\
\text { LCC5082 } \\
\text { LCC0592 }\end{array}$ \\
\hline 9 & $2.48 \pm 0.07$ & $\begin{array}{l}\text { S. epidermidis (8) } \\
\text { S. aureus ( } 2 \text { ) }\end{array}$ & 4 & $\begin{array}{l}\text { LI508I } \\
\text { LI5094 } \\
\text { LIRBI } \\
\text { LIRB2 }\end{array}$ \\
\hline 10 & $2.25 \pm 0.10$ & S. epidermidis (10) & 2 & $\begin{array}{l}\text { LV508I } \\
\text { LV5RB3 }\end{array}$ \\
\hline II & $2.41 \pm 0.12$ & S. epidermidis (I0) & 2 & $\begin{array}{l}\text { LG5082a } \\
\text { LGRBI }\end{array}$ \\
\hline 12 & $2.51 \pm 0.22$ & S. epidermidis (I0) & I & $24 \mathrm{Cl} 3$ \\
\hline
\end{tabular}




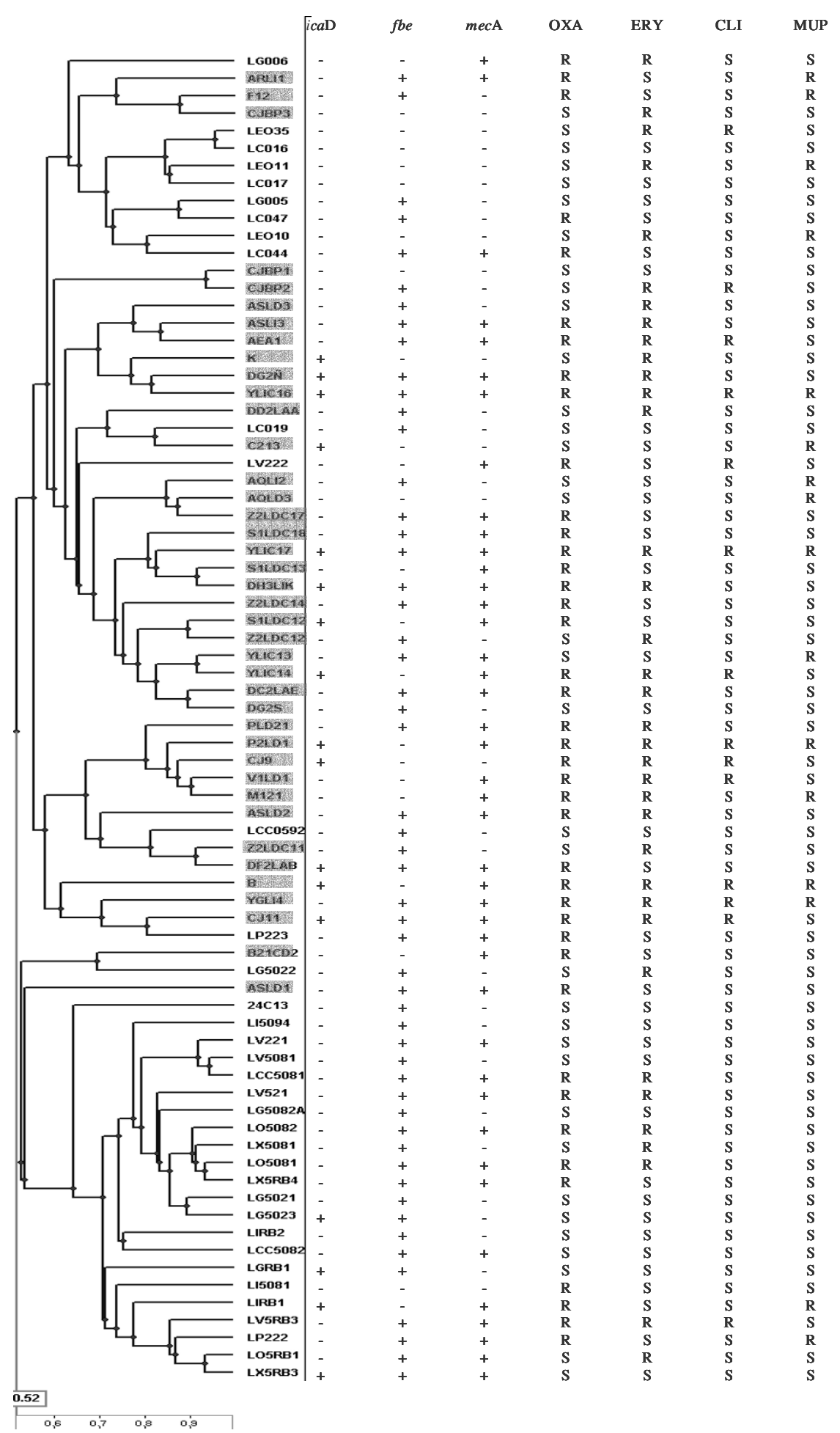

Figure I

Dendogram obtained by PFGE analysis of the $S$. epidermidis strains from mastitis and healthy women. Strains isolated from mastitis-suffering women are shaded. Information on the presence of icaD, fbe and mecA genes and resistance to oxacillin (OXA; MIC > $2 \mu \mathrm{g} \mathrm{mL}-1$ ), erythromycin (ERY; MIC $>4 \mu \mathrm{g} \mathrm{mL}-1$ ), clindamycin (CLY; MIC $>2 \mu \mathrm{g} \mathrm{mL}-1$ ) and mupirocin (MUP; MIC > $5 \mathrm{I} 2 \mu \mathrm{g} \mathrm{mL}-1$ ) has been included. 
Table 2: Distribution of MIC's to several antibiotics among S. epidermidis isolated from mastitis and healthy women

\begin{tabular}{|c|c|c|c|c|c|c|c|c|c|c|c|c|}
\hline \multirow[b]{2}{*}{ Antibiotics } & \multirow[b]{2}{*}{ Breast milk } & \multirow[b]{2}{*}{$\mathrm{N}^{\circ}$ of strains } & \multicolumn{10}{|c|}{ Percentage of strains for which the MIC $\left(\mu \mathrm{g} \mathrm{mL}^{-1}\right)$ was as follows: } \\
\hline & & & $\leq 0.03$ & 0.12 & 0.25 & 0.5 & 1 & 2 & 4 & 8 & $>8$ & \\
\hline \multirow[t]{2}{*}{ PEN } & $\mathrm{H}$ & 36 & 17 & 8 & & 8 & 14 & 14 & 8 & 11 & 19 & \\
\hline & M & 40 & 10 & 5 & 5 & 8 & 10 & 33 & 8 & 8 & 18 & \\
\hline \multirow[t]{3}{*}{ AMP } & & & & $\leq 0.12$ & 0.25 & 0.5 & 1 & 2 & 4 & 8 & 100 & $>100$ \\
\hline & $\mathrm{H}$ & 36 & & 19 & 6 & 17 & 22 & 8 & 8 & 6 & 14 & \\
\hline & $M$ & 40 & & 15 & 8 & 5 & 23 & 20 & 10 & 5 & 13 & 3 \\
\hline \multirow[t]{3}{*}{ OXA } & & & & & $\leq 0.25$ & 0.5 & I & 2 & $>2$ & & & \\
\hline & $\mathrm{H}$ & 36 & & & 11 & 31 & 11 & 8 & 39 & & & \\
\hline & $M$ & 40 & & & 5 & 8 & 13 & 8 & 68 & & & \\
\hline \multirow[t]{3}{*}{ CIP } & & & & & $\leq 0.25$ & 0.5 & I & 2 & $>2$ & & & \\
\hline & $\mathrm{H}$ & 36 & & & 47 & 39 & 8 & & 6 & & & \\
\hline & $M$ & 40 & & & 30 & 38 & 18 & 3 & 13 & & & \\
\hline \multirow[t]{3}{*}{$\mathrm{CHL}$} & & & & & & & & & & $\leq 8$ & 16 & $>16$ \\
\hline & $\mathrm{H}$ & 36 & & & & & & & & 75 & 17 & 8 \\
\hline & $M$ & 40 & & & & & & & & 78 & 10 & 13 \\
\hline \multirow[t]{3}{*}{ ERY } & & & & & $\leq 0.25$ & 0.5 & I & 2 & 4 & $>4$ & & \\
\hline & $\mathrm{H}$ & 36 & & & 39 & 14 & 6 & 8 & & 33 & & \\
\hline & $M$ & 40 & & & 23 & 15 & & & 3 & 60 & & \\
\hline \multirow[t]{3}{*}{ CLI } & & & & & & $\leq 0.5$ & 1 & 2 & $>2$ & & & \\
\hline & $\mathrm{H}$ & 36 & & & & 81 & 8 & 3 & 8 & & & \\
\hline & $M$ & 40 & & & & 70 & 3 & & 28 & & & \\
\hline \multirow[t]{3}{*}{ TET } & & & & & & & & & $\leq 4$ & 8 & $>8$ & \\
\hline & $\mathrm{H}$ & 36 & & & & & & & 56 & 19 & 25 & \\
\hline & $M$ & 40 & & & & & & & 68 & 8 & 25 & \\
\hline \multirow[t]{3}{*}{ VAN } & & & & & & $\leq 0.5$ & 1 & 2 & 4 & 8 & 16 & $\geq 16$ \\
\hline & $\mathrm{H}$ & 36 & & & & & 44 & 50 & 6 & & & \\
\hline & $M$ & 40 & & & & & 43 & 48 & 5 & 3 & 3 & \\
\hline \multirow[t]{3}{*}{ MUP } & & & & & & & & & $\leq 4$ & 256 & $>256$ & \\
\hline & $\mathrm{H}$ & 36 & & & & & & & 78 & 11 & II & \\
\hline & $M$ & 40 & & & & & & & 58 & 13 & 30 & \\
\hline
\end{tabular}

$\mathrm{H}$ : strains isolated from healthy women; M: strains isolated from mastitis-suffering women; PEN: penicillin; AMP: ampicillin; OXA: oxacillin; CIP: ciprofloxacin; CHL: chloramphenicol; ERY: erythromycin; CLI: clindamycin; TET: tetracycline; VAN: vancomycin; MUP: mupirocin. Statistically-significant differences between isolates from mastitis and healthy women are in bold. 
results against the rest of antibiotics were variable depending on the strains (Table 2). Independently of their origin, most of the strains were sensitive to trimethoprim/sulfamethoxazole (MIC $<2 / 38 \mu \mathrm{g} \mathrm{mL}^{-1}$ for $90 \%$ of the strains), gentamicyn $(\leq 2 \mu \mathrm{g} \mathrm{mL}-1$ for $87 \%)$, linezolid $(\leq 2 \mu \mathrm{g} \mathrm{mL}$ ${ }^{1}$ for $\left.86 \%\right)$, fosfomicyn ( $\leq 16 \mu \mathrm{g} \mathrm{mL}^{-1}$ for $\left.82 \%\right)$, ciprofloxacin $\left(\leq 0,5 \mu \mathrm{g} \mathrm{mL}^{-1}\right.$ for $\left.76 \%\right)$, tetracycline $(\leq 8 \mu \mathrm{g} \mathrm{mL}$ ${ }^{1}$ for $\left.75 \%\right)$, chloramphenicol ( $\leq 16 \mu \mathrm{g} \mathrm{mL}^{-1}$ for $\left.90 \%\right)$, penicillin $\left(\leq 4 \mu \mathrm{g} \mathrm{mL}^{-1}\right.$ for $\left.72 \%\right)$, ampicillin $\left(\leq 4 \mu \mathrm{g} \mathrm{mL}^{-1}\right.$ for $80 \%)$ and the glycopeptides vancomycin $\left(\leq 2 \mu \mathrm{g} \mathrm{mL}^{-1}\right.$ for $93 \%)$ and teicoplanin $\left(\leq 1 \mu \mathrm{g} \mathrm{mL}^{-1}\right.$ for $\left.70 \%\right)$. The percentage of susceptible strains was lower for imipenem $(\leq 0,12$ $\mu \mathrm{g} \mathrm{mL}^{-1}$ for $\left.58 \%\right)$ and quinupristin/dalfopriscin $(\leq 0,25 \mu \mathrm{g}$ $\mathrm{mL}^{-1}$ for $57 \%$ ). However, significant differences were observed in the percentage of strains resistant to some antibiotics depending on their origin (Figure 1). For instance, $43 \%$ of isolates from mastitic samples showed a MIC of mupirocin $\geq 512 \mu \mathrm{g} \mathrm{mL}^{-1}$ while only $22 \%$ of those isolated from non-mastitic samples reached this value ( $P$ $=0,0437)$. Similarly, $60 \%$ of the mastitic-related strains showed a MIC $>4 \mu \mathrm{g} \mathrm{mL}^{-1}$ against erythromycin in contrast to $33 \%$ of the other group $(P=0,0201)$. In the case of clindamycin, $28 \%$ of the strains from mastitic milk presented a MIC $>2 \mu \mathrm{g} \mathrm{mL}^{-1}$ while the percentage was of $8 \%$ in strains from healthy women $(P=0,0314)$. A higher percentage of oxacillin resistance (MIC $>2 \mu \mathrm{g} \mathrm{mL}^{-1}$ ) was also found among the strains from mastitis $(68 \%)$ than those from healthy mothers $(39 \%)(P=0,0125)$. Finally, two strains from women with mastitis (CJ11 and DG2S) were resistant to streptomycin (> $\left.1000 \mu \mathrm{g} \mathrm{mL}^{-1}\right)$ and one strain (AQLI2) from the same group was resistant to vancomycin $\left(16 \mu \mathrm{g} \mathrm{mL}^{-1}\right)$. No strains resistant to these two antibiotics were found among the strains from healthy women.

\section{Presence of mecA and SCCmec typing}

Among the 41 strains showing oxacillin resistance, the mecA gene could be detected by PCR in 37 (25 from mastitic milk and 12 from milk of healthy women). No amplification was observed in two strains of each group (F12 and CJ9; LI5081 and LC047, respectively), which had shown an oxacillin MIC value of $>2 \mu \mathrm{g} \mathrm{mL}^{-1}$. In contrast, the mecA gene was detected in five oxacillin susceptible strains, one from a mastitis case (YLIC13) and four from healthy women (LO5RB1, LX5RB3, LV221 and LCC 5082).

The type of SCCmec was determined in all the mecA+ strains. The $c c r \mathrm{~B}$ gene could be amplified from 22 of the $26 \mathrm{mec}^{+}$strains from the mastitis group and, on the basis of the $c r$ B restriction pattern with HinfI (type IV: 264, 227 and 154 bp; type III: 537 and 106 bp) or with Hinfl/BsmI (type IV: 227, 171, 153 and 93 bp; type III: 320, 174, 106 and $44 \mathrm{bp}), 19$ strains were assigned to type IV and the remaining three (S1LDC12, Z2LDC17 and DF2LAB) to type III (see additional file 1). Amplification of $c \mathrm{crB}$ was achieved in the $16 \mathrm{mec}^{+}$strains from healthy women and, among them, 14 strains showed type IV and two type III SCCmec. The application of the full assay described by Zhang et al. [12] confirmed these results. The $4 \mathrm{mecA}^{+}$ strains that could not be typed on the basis of their $c c r B$ restriction pattern remained non typeable with the full Zhang et al. assay.

\section{Discussion}

S. epidermidis is a normal inhabitant of the skin and mucosal surfaces in healthy hosts and its ubiquitous prevalence as a commensal species makes difficult for a clinician to decide if an isolate represents the etiological agent or a culture contamination [11]. Therefore, isolation of this bacterial species is generally regarded as non-related to a mastitis case, even when it is the only species present in a milk sample [4].

S. epidermidis was the dominant or unique staphylococcal species in breast milk of women suffering mastitis, a finding described previously [4], which indicates that this bacterial species could be an etiological agent of human lactational mastitis. Similarly, several studies have shown the implication of this bacterial species as an agent of mastitis in different animal species [13-15].

The genotyping of the S. epidermidis isolates by PFGE revealed a low diversity within this species in the breast milk of women with mastitis, with a mean of 2 different profiles per sample. A lost in the microbial diversity present in milk of women with mastitis has been previously pointed [4]. Comparison by PFGE dendogram analysis of these strains with those obtained from breast milk of healthy women showed the existence of two main clusters and, within these two groups, the strains generally matched with the origin (mastitis and healthy women). However, a few strains from healthy women grouped together with the mastitis cluster reflecting a similar genetic background. The fact that their presence in milk of healthy women does not constitute a health problem could indicate that a predisposal host is also need for $S$. epidermidis to develop an infection [16].

Among the S. epidermidis strains analyzed, the presence of adhesion-related genes was high independently of the condition of the women from which they were isolated. The presence of genes encoding cell surface proteins may explain, at least partially, the high prevalence of $S$. epidermidis in breast milk, mammary areola and ducts of both healthy and mastitis-suffering women. In contrast, the percentage of strains carrying the biofilm-related ica operon was higher in strains from mastitis milk than in that obtained from healthy women. A potential relationship between $S$. epidermidis infection and the presence of such operon has been reported [8]. In fact, biofilm forma- 
tion has been described in many cases of staphylococcal mastitis and this is the reason why such property is considered as a potential virulence factor $[17,18]$.

Strains belonging to either the mastitis or the healthy women group showed a similar susceptibility against many of the antibiotics tested; however, a higher percentage of mupirocin-, erythromycin-, clindamicyn- and oxacillin-resistant strains was found among those isolated from mastitic milk. Resistance to these and other antibiotics in pathogenic $S$. epidermidis isolates has been reported previously $[10,19]$. The resistance of these strains could be partly due to the increasing use of broad-spectrum antibiotics, which encourage selection of multirresistant strains [11]. Improper antibiotherapy may explain why staphylococcal mastitis frequently becomes a chronic and/or recurrent infection. In this study, the presence of mecA gene accompanied with resistance to oxacillin (MIC $>2 \mu \mathrm{g} \mathrm{mL}$ ${ }^{1}$ ) was observed in $62 \%$ of the strains from mastitis, but only in 33\% from the healthy group. The mecA gene was not detected in four oxacillin-resistant strains. These strains may represent cases of borderline resistance which is characterized by an oxacillin MIC at or just above the susceptibly breakpoint ( 4 to $8 \mu \mathrm{g} \mathrm{mL}^{-1}$ ). In contrast, the $m e c \mathrm{~A}$ gene was detected in five oxacillin-susceptible strains, a fact that has been previously described [20] and that may be due to gene deletions.

Methicillin-resistant Staphylococcus aureus (MRSA) are being reported with increasing frequency in the community and they have been called community-acquired (CA)MRSA, which are associated with skin and soft tissue infection [21] but are also frequently isolated from healthy hosts [22]. Most of the $m e c \mathrm{~A}^{+}$strains used in this study could be ascribed to type IV SCCmec. In S. epidermidis, some studies have reported that SCCmec type IV is generally carried by CA-MRS $[23,24]$ but this type seems to be predominant among clinically relevant $S$. epidermidis isolates [9]. The fact that the ccrB gene was not amplified from four $m e c \mathrm{~A}^{+}$strains may be due to the presence of different alleles for this gene [25].

In the last years, a renewed medical and research interest has been focused on S. epidermidis since it has become the most important cause of nosocomial infections [6]. The complete genome analysis of some methicillin-resistant $S$. aureus and $S$. epidermidis strains of human origin have revealed the propensity of $S$. aureus to cause fulminant and sometimes life-threatening infections, as opposed to the predisposition of $S$. epidermidis for chronic and recurrent infections [26]. Identification of S. epidermidis as etiological agents of infection is sometimes hindered by the fact that infections associated with this microorganims are characterized by subtle, non-specific clinical manifestations [5]. Precisely, these characteristics occur in most cases of lactational mastitis. Genome flexibility in S. epidermidis may contribute to the acquisition of some transferable virulence and resistant traits $[6,27]$ and to the evolution of this species from a commensal to a pathogenic microorganism in susceptible hosts [28]. In fact, it seems that there is an important host factor in lactational mastitis since a woman having such condition usually displays the same clinical signs after subsequent pregnancies. Additionally, it would explain why only a $3-30 \%$ of lactating women suffer from such infection when it is the predominant bacterial species found in breast milk of healthy women $[29,30]$.

\section{Conclusion}

Staphylococcus epidermidis is the most prevalent staphylococcal species isolated from breast milk of women suffering mastitis, where it is present at a concentration notably higher than that present in milk of healthy woman $(\geq 4.0$ versus $\leq 3.0 \log _{10}$ cfu $\mathrm{mL}^{-1}$, respectively). The percentage of strains showing biofilm production ability and resitance to mupirocin, erythromycin, clindamicyn and/or methicillin was significantly higher among those obtained from women with lactational mastitis than among those isolated from healthy women.

The random method used to select staphylococcal colonies from the samples could introduce a bias regarding the low number of samples from which $S$. aureus was isolated. Traditionally, S. aureus has been considered as the main etiological agent of mastitis. However, the results of this work suggest that $S$. epidermidis could be an additional and underrated cause of lactational mastitis; as a consequence, its presence should be also considered in bacteriological analyses of human milk when there is a suspicious of a mastitis infection. Further studies involving a larger number of samples and staphylococcal isolates will be required to confirm the results obtained in this study.

\section{Methods}

\section{Samples and isolation of staphylococcal isolates}

A total of 30 women aged 25-34 years with clinical symptoms of infectious mastitis participated in the study (Table $1)$. They were diagnosed by the lactation consultants attending different primary health-care centers in Spain in a 2-months period (October-November 2007). The total staphylococcal count was higher $\geq 4 \log _{10} \mathrm{cfu} \mathrm{mL}^{-1}$ in all their samples. Women with mammary abscesses or any kind of parallel diseases and patients treated with antibiotherapy during the previous two weeks of the study were excluded. All volunteers gave written informed consent to the protocol, which was approved by the Ethical Committee of Hospital Clínico of Madrid (Spain). The milk samples were collected as described previously [31], and plated onto ready to use Baird Parker (BP) plates supplied 
by bioMérieux (Marcy l'Etoile, France). The plates were incubated in aerobiosis at $37^{\circ} \mathrm{C}$ for $48 \mathrm{~h}$.

\section{Identification of staphylococci}

Initially, a total of 270 isolates ( 10 from each sample displaying bacterial growth on BP plates) were randomly selected and tested for catalase and coagulase activities and for their resistance to lysozyme and lysostaphin [32]. All of them were subjected to a novel multiplex PCR method designed to allow a rapid identification of S. epidermidis and $S$. aureus isolates. The new primers (see below) were designed on the basis of the variable regions of the tuf gene sequence of Staphylococcus using the program Clone Manager Suite 7.0 (Sci Ed Central, USA). Their specificity was tested in silico by PCR simulation against up-to-date sequenced prokaryotic genomes using the tools provided in the website http://insilico.ehu.es/ PCR. Briefly, a colony of each isolate was suspended in 20 $\mu \mathrm{L}$ of TE buffer (10 M Tris-HCl, $1 \mathrm{M}$ EDTA pH 8) with $0.9 \% \mathrm{NaCl}$, and after heating at $98^{\circ} \mathrm{C}$ for $10 \mathrm{~min}$, the suspension $(5 \mu \mathrm{L})$ was used as a template for PCR using the BioredMix (BioLine, London, UK) system and the primers $(10 \mu \mathrm{M})$ tuf-g (5'-GGTGTACCAGCATTAGT-3'), tuf-a (5'TTCAGTATGTGGTGTAA-3') and tuf-e (5'-TTCGTGCATACCGATGA-3'). The primer pairs tuf-g/tuf-e and tuf-g/tufa result in a $370 \mathrm{bp}$ (S. epidermidis) or a $530 \mathrm{bp}$ (S. aureus) fragment [see additional file 2]. PCR conditions were 1 cycle of $94^{\circ} \mathrm{C}$ for $5 \mathrm{~min}, 30$ cycles of $94^{\circ} \mathrm{C}$ for $1 \mathrm{~min}, 48^{\circ} \mathrm{C}$ for $1 \mathrm{~min}$, and $72^{\circ} \mathrm{C}$ for $2 \mathrm{~min}$, and a final extension of $72^{\circ} \mathrm{C}$ for $5 \mathrm{~min}$. Identification of the isolates was confirmed by PCR sequencing of a $470 \mathrm{bp}$ fragment of the $16 \mathrm{~S}$ rRNA gene using primers and conditions previously described [33]. The amplicons were purified using the Nucleospin ${ }^{\circledast}$ Extract II kit (Macherey-Nagel, Düren, Germany) and sequenced at the Genomics Unit of the Universidad Complutense de Madrid, Spain.

\section{Genotyping of S. epidermidis isolates by pulsed field gel electrophoresis (PFGE)}

To determine the diversity of $S$. epidermidis in breast milk in mastitis infections, 200 isolates of this species obtained from 26 women with mastitis were subjected to PFGE genotyping together with 105 isolates of the same species obtained from breast milk of 12 healthy women within the same period of time [34] (Table 1). Chromosomal DNA was digested with the endonuclease SmaI (New England Biolabs, Ipswich, MA) at $37^{\circ} \mathrm{C}$ for $16 \mathrm{~h}$. Electrophoresis was carried out in a CHEF DR-III apparatus (BioRad Laboratories, Hercules, CA) for $23 \mathrm{~h}$ at $14^{\circ} \mathrm{C}$ at $6 \mathrm{~V}$ $\mathrm{cm}^{-1}$ with pulses from 5 to $50 \mathrm{~s}$. A standard pattern (Lamda Ladder PFG Marker, New England Biolabs) was included in the gels to allow comparison of the digitally normalized PFGE profiles. Computer-assisted analysis of the gels was performed with the Phoretix 1D Pro software (Nonlinear USA, Inc., Durham, NC). PFGE profiles differ- ing in one or more fragments were considered different. Cluster analysis of the PFGE patterns was performed using the UPGMA method based on the Dice similarity coefficient.

\section{Screening for potential virulence determinants}

On the basis of the different PFGE profiles, 76 strains (40 from mastitis cases and 36 from healthy women) were further selected and characterized. Presence of genes embp, $f b e$, at $\mathrm{E}$ and ica $\mathrm{D}$, which respective products are involved in adhesion and biofilm formation, was evaluated using primers couples described previously [7,35-37]. In the case of $f b e$, at $l \mathrm{E}$ and icaD, a multiplex PCR format was designed using the following conditions: $5 \mathrm{~min}$ at $94^{\circ} \mathrm{C}$ followed by 30 cycles of $94^{\circ} \mathrm{C}$ for $1 \mathrm{~min}, 60^{\circ} \mathrm{C}$ for $30 \mathrm{~s}$, $72^{\circ} \mathrm{C}$ for $1 \mathrm{~min}$ and, then, a final extension of $5 \mathrm{~min}$ at $72^{\circ} \mathrm{C}$ [see additional file 3]. Strains isolated from mastitic milk were compared to those isolated from healthy women. Data were subjected to a statistical analysis using the Chi-square test (SPSS package, SPSS Inc, Chicago, IL, USA). Differences were considered significant if $P$ values were lower than 0.05 .

\section{Phenotypic assays}

The hemolytic activity of the isolates was determined on Columbia agar supplemented with $5 \%$ horse blood $\left(\mathrm{COH}\right.$, bioMériux) after incubation at $37^{\circ} \mathrm{C}$ for $72 \mathrm{~h}$ following a procedure previously described [32]. The ability of the isolates to form slime was assessed using the Congo Red agar assay (CRA) [38]. The plates were incubated at $37^{\circ} \mathrm{C}$ for $24 \mathrm{~h}$ and, then, for additional $24 \mathrm{~h}$ at room temperature.

\section{Determination of MIC's to antibiotics}

The determination of the MIC's to several antibiotics commonly used against staphylococcal infections was evaluated by a microdilution method using the Sensititre plates Staenc1F (Trek Diagnostic Systems, Cleveland, OH) following the manufacturer's instructions. The antibiotics analyzed were: penicillin, ampicillin, amoxycillin-clavulanic acid, teicoplanin, chloramphenicol, erythromycin, mupirocin, streptomycin, gentamicin, clindamycin, oxacillin, ciprofloxacin, fosfomycin, imipenem, nitrofurantoine, trimethoprim-sufamethoxazole, tetracycline, vancomycin, linezolid, quinupristin-dalfopristin and rifampin. Data were submitted to the statistical analysis described above.

Screening for mecA gene and typing of the staphylococcal chromosome cassette mec (SSCmec)

Presence of the mecA gene was evaluated by PCR using primers mecA forward (5'-GGTCCCATTAACTCTGAAG-3') and mecA reverse (5'-AGTTCTGCAGTACCGGATTTTGC3 '), which results in a 1,040 bp fragment [39]. The SCCmec was subjected to a typing procedure [40], which 
implied the PCR amplification of the $c c r B$ gene followed by RFLP analysis using endonucleases Hinfl and BsmI. Presence of mecA and SCCmec typing was confirmed using all the primers and conditions described by Zhang et al. [12].

\section{Authors' contributions}

$\mathrm{SD}$ carried out the microbiological analysis of the samples, designed the primers and multiplex PCR conditions and drafted the manuscript. RA assisted in the preparation of material and in the identification of the isolates. EJ and MLM participated in the characterization of the strains. RC set up and helped with the PFGE methodology. LF participated in the design of the study and performed the statistical analysis. JMR conceived of the study, coordinated it and revised the manuscript. All authors read and approved the final manuscript.

\section{Additional material}

\section{Additional file 1}

PCR-RFLP of the ccrB gene using endonucleases HinfI and HinfI/ BsmI. The figure provided shows the profiles of SCCmec types III and IV using the method of Yang et al. [40]. In lanes 1 and $3 \mathrm{ccrB}$ amplicons are cut with HinfI whereas in lanes 2 and 4 the amplicons are cut with HinfI and BsmI. Lanes 1 and 2: S. epidermidis DF2LAB, SCCmec type III (537, $106 \mathrm{bp}$ and 320,174, 106 bp respectively); lanes 3 and 4: S. epidermidis V1LD1, SCCmec type IV $(264,227,154$ and 227, 171, 153, 93 bp respectively); $M$, molecular weight marker. Click here for file

[http://www.biomedcentral.com/content/supplementary/14712180-9-82-S1.pdf]

\section{Additional file 2}

Multiplex tuf gene-based PCR assay for the specific identification of $\mathrm{S}$. aureus and $\mathrm{S}$. epidermidis. The figure provided shows the respective species-specific bands. Lanes: 1-5, S. aureus isolates; 6-9, S. epidermidis isolates, 10, negative control; M, molecular weight marker (100 bp Ladder, Invitrogen).

Click here for file

[http://www.biomedcentral.com/content/supplementary/14712180-9-82-S2.pdf]

\section{Additional file 3}

Multiplex PCR assay for the simultaneous detection of three adhesionor biofilm-related genes. The figure provided shows the respective genespecific bands. Lanes: 1, S. epidermidis CJBP2; 2, S. epidermidis V1LD1; 3, S. epidermidis DG2S; 4, S. epidermidis P2LD1; 5, S. epidermidis S1LDC13; 6 , negative control; $M$, molecular weight marker. atlE gene: $682 \mathrm{bp}$; fbe gene: $496 \mathrm{bp}$; icaD gene: $225 \mathrm{bp}$.

Click here for file

[http://www.biomedcentral.com/content/supplementary/14712180-9-82-S3.pdf]

\section{Acknowledgements}

This work was supported by the FUN-C-FOOD (Consolider-Ingenio 2010) and AGL2007-62042 projects from the Ministerio de Educación y Ciencia
(Spain). S. Delgado was the recipient of a postdoctoral fellowship from the same Ministry. We are grateful to $\mathrm{H}$. Herrero and the Association "Amamantar" (Avilés, Asturias) for their collaboration in the collection of the milk samples analyzed in this study.

\section{References}

I. World Health Organization (WHO): Mastitis: Causes and Management. In WHO/FCH/CAH/00.13 Geneva, Switzerland: Dept. of child and adolescent health and development; 2000.

2. Foxman B, D'Arcy H, Gillespie B, Bobo JK, Schwartz K: Lactation mastitis: occurrence and medical management among 946 breastfeeding women in the United States. Am J Epidemiol 2002, 155:103-114.

3. Lawrence RA, Lawrence RM: Breastfeeding. A Guide for the Medical Profession 6th edition. St. Louis: Mosby; 2005.

4. Delgado S, Arroyo R, Martin R, Rodriguez JM: PCR-DGGE assessment of the bacterial diversity of breast milk in women with lactational infectious mastitis. BMC Infect Dis 2008, 8:5I.

5. von Eiff C, Peters G, Heilmann C: Pathogenesis of infections due to coagulase-negative staphylococci. Lancet Infect Dis 2002, 2:677-685.

6. Ziebuhr W, Hennig S, Eckart M, Kranzler H, Batzilla C, Kozitskaya S: Nosocomial infections by Staphylococcus epidermidis: how a commensal bacterium turns into a pathogen. Int J Antimicrob Agents 2006, 28(Suppl I):SI4-S2O.

7. Frebourg NB, Lefebvre S, Baert S, Lemeland JF: PCR-based assay for discrimination between invasive and contaminating Staphylococcus epidermidis strains. J Clin Microbiol 2000, 38:877-880.

8. Vandecasteele SJ, Peetermans WE, Merckx R, Rinders BJ, Van Eldere $\mathrm{J}:$ Reliability of the ica, aap, and at/E genes in the discrimination between invasive, colonizing and contaminant Staphylococcus epidermidis isolates in the diagnosis of catheterrelated infections. Clin Microbiol Infect 2003, 9:II4-II9.

9. Wisplinghoff $H$, Rosato $A E$, Enright $M C$, Noto $M$, Craig $W$, Archer GL: Related clones containing SCCmec type IV predominate among clinically significant Staphylococcus epidermidis isolates. Antimicrob Agents Chemother 2003, 47:3574-3579.

10. Luthje P, Schwarz S: Antimicrobial resistance of coagulase-negative staphylococci from bovine subclinical mastitis with particular reference to macrolide-lincosamide resistance phenotypes and genotypes. I Antimicrob Chemother 2006, 57:966-969.

II. Casey AL, Lambert PA, Elliott TSJ: Staphylococci. Int J Antimicrob Agents 2007, 29(Suppl 3):S23-S32.

12. Zhang K, McClure JA, Elsayed S, Louie T, Conly JM: Novel multiplex PCR assay for characterization and concomitant subtyping of staphylococcal cassette chromosome mec types I to $V$ in methicillin-resistant Staphylococcus aureus. J Clin Microbiol 2005, 43:5026-5033.

13. Zhang S, Maddox CW: Cytotoxic activity of coagulase-negative staphylococci in bovine mastitis. Infect Immun 2000, 68: $1102-1108$.

14. dos Santos Nascimento J, Fagundes PC, de Paiva Brito MA, dos Santos KR, do Carmo de Freire Bastos M: Production of bacteriocins by coagulase-negative staphylococci involved in bovine mastitis. Vet Microbiol 2005, 106:6I-7I.

15. Thorberg BM, Kuhn I, Aarestrup FM, Brandstrom B, Jonsson P, Danielsson-Tham ML: Pheno- and genotyping of Staphylococcus epidermidis isolated from bovine milk and human skin. Vet Microbiol 2006, I I5:163-I72.

16. Vuong C, Kocianova S, Yu J, Kadurugamuwa JL, Otto M: Development of real-time in vivo imaging of device-related Staphylococcus epidermidis infection in mice and influence of animal immune status on susceptibility to infection. J Infect Dis 2008, 198:258-61.

17. Melchior MB, Vaarkamp H, Fink-Gremmels J: Biofilms: $\mathbf{A}$ role in recurrent mastitis infections? Vet / 2006, I 7 I:398-407.

18. Oliveira M, Bexiga R, Nunes SF, Carneiro C, Cavaco LM, Bernardo F, Vilela CL: Biofilm-forming ability profiling of Staphylococcus aureus and Staphylococcus epidermidis mastitis isolates. Vet Microbiol 2006, I I 8: I 33-140.

19. Martineau F, Picard FJ, Lansac N, Menard C, Roy PH, Ouellette M, Bergeron MG: Correlation between the resistance genotype determined by multiplex PCR assays and the antibiotic sus- 
ceptibility patterns of Staphylococcus aureus and Staphylococcus epidermidis. Antimicrob Agents Chemother 2000, 44:23I-238.

20. Donnio PY, Oliveira DC, Faria NA, Wilhelm N, Le Coustumier A, de Lencastre $\mathrm{H}$ : Partial excision of the chromosomal cassette containing the methicillin resistance determinant results in methicillin-susceptible Staphylococcus aureus. J Clin Microbiol 2005, 43:4I9I-4I93.

2I. Eady EA, Cove JH: Staphylococcal resistance revisited: community-acquired methicillin resistant Staphylococcus aureusan emerging problem for the management of skin and soft tissue infections. Curr Opin Infect Dis 2003, 16:103-124.

22. Zaoutis TE, Toltzis P, Chu J, Abrams T, Dul M, Kim J, McGowan KL, Coffin SE: Clinical and molecular epidemiology of communityacquired methicillin-resistant Staphylococcus aureus infections among children with risk factors for health care-associated infection: 200 I-2003. Pediatr Infect Dis J 2006, 25:343-348.

23. Hisata K, Kuwahara-Arai K, Yamanoto M, Ito T, Nakatomi $Y$, Cui L, Baba T, Terasawa M, Sotozono C, Kinoshita S, Yamashiro Y, Hiramatsu K: Dissemination of methicillin-resistant staphylococci among healthy Japanese children. J Clin Microbiol 2005, 43:3364-3372

24. Jamaluddin TZ, Kuwahara-Arai K, Hisata K, Terasawa M, Cui L, Baba T, Sotozono C, Kinoshita S, Ito T, Hiramatsu K: Extreme genetic diversity of methicillin-resistant Staphylococcus epidermidis strains disseminated among healthy Japanese children. J Clin Microbiol 2008, 46:3778-3383.

25. Oliveira DC, Milheirico C, Vinga S, de Lencastre H: Assessment of allelic variation in the ccrAB locus in methicillin-resistant Staphylococcus aureus clones. I Antimicrob Chemother 2006, 58:23-30.

26. Gill SR, Fouts DE, Archer GL, Mongodin EF, Deboy RT, Ravel J, Paulsen IT, Kolonay JF, Brinkac L, Beanan M, Dodson RJ, Daugherty SC, Madupu R, Angiuoli SV, Durkin AS, Haft DH, Vamathevan J, Khouri H, Utterback T, Lee C, Dimitrov G, Jiang L, Qin H, Weidman J, Tran K, Kang K, Hance IR, Nelson KE, Fraser CM: Insights on evolution of virulence and resistance from the complete genome analysis of an early methicillin-resistant Staphylococcus aureus strain and a biofilm-producing methicillin-resistant Staphylococcus epidermidis strain. J Bacteriol 2005, I 87:2426-2438.

27. Kozitskaya S, Cho SH, Dietrich K, Marre R, Naber K, Ziebuhr W: The bacterial insertion sequence element IS256 occurs preferentially in nosocomial Staphylococcus epidermidis isolates: association with biofilm formation and resistance to aminoglycosides. Infect Immun 2004, 72:1210-1215.

28. Vuong C, Otto M: Staphylococcus epidermidis infections. Microbes Infect 2002, 4:48I-489.

29. Martín R, Heilig HG, Zoetendal EG, Jiménez E, Fernández L, Smidt H, Rodríguez JM: Cultivation-independent assessment of the bacterial diversity of breast milk among healthy women. Res Microbiol 2007, 158:31-37.

30. Heikkila MP, Saris PE: Inhibition of Staphylococcus aureus by the commensal bacteria of human milk. J Appl Microbiol 2003, 95:47I-478

31. Martín R, Jiménez E, Heilig H, Fernández L, Marín ML, Zoetendal E, Rodríguez JM: Isolation of bifidobacteria from breast milk and assessment of the bifidobacterial population by PCR-DGGE and qRTi-PCR. Appl Environ Microbiol 2009, 75:965-969.

32. Freney J, Kloos WE, Hajek V, Webster JA, Bes M, Brun Y, VernozyRozand C: Recommended minimal standards for description of new staphylococcal species. Subcommittee on the taxonomy of staphylococci and streptococci of the International Committee on Systematic Bacteriology. Int J Syst Bacteriol 1999, 49:489-502

33. Kullen MJ, Sanozky-Dawes RB, Crowell DC, Klaenhammer TR: Use of the DNA sequence of variable regions of the 16S rRNA gene for rapid and accurate identification of bacteria in the Lactobacillus acidophilus complex. J Appl Microbiol 2000, 89:5||-5|6.

34. Jiménez E, Delgado S, Maldonado A, Arroyo R, Albújar M, García N Jariod M, Fernández L, Gómez A, Rodríguez JM: Staphylococcus epidermidis: a differential trait of the fecal microbiota of breastfed infant. BMC Microbiology 2008, 8: 143.

35. Nilsson M, Frykberg L, Flock Jl, Pei L, Lindberg M, Guss B: A fibrinogen-binding protein of Staphylococcus epidermidis. Infect Immun 1998, 66:2666-2673.
36. Williams RJ, Henderson B, Sharp LJ, Nair SP: Identification of a Fibronectin-binding protein from Staphylococcus epidermidis. Infect Immun 2002, 70:6805-68I0.

37. Cafiso V, Bertuccio T, Santagati M, Campanile F, Amicosante G, Perilli MG, Selan L, Artini M, Nicoletti G, Stefani S: Presence of ica operon in clinical isolates of Staphylococcus epidermidis and its role in biolfilm production. Clin Microbiol Infect 2004, 10:108I-1088.

38. Freeman DJ, Falkiner F, Keane CT: New method for detecting slime production by coagulase negative staphylococci. J Clin Pathol 1989, 34:143-I47.

39. Cafiso V, Campanile F, Borbone S, Caia A, Cascone C, Santagati M, Stefani S: Correlation between methicillin-resistance and resistance to fluoroquinolones in Staphylococcus aureus and Staphylococcus epidermidis. Infez Med 200I, 2:90-97.

40. Yang JA, Park DW, Sohn JW, Kim MJ: Novel PCR-restriction fragment length polymorphism analysis for rapid typing of staphylococcal cassette chromosome mec elements. J Clin Microbiol 2006, 44:236-238.
Publish with Bio Med Central and every scientist can read your work free of charge

"BioMed Central will be the most significant development for disseminating the results of biomedical research in our lifetime. "

Sir Paul Nurse, Cancer Research UK

Your research papers will be:

- available free of charge to the entire biomedical community

- peer reviewed and published immediately upon acceptance

- cited in PubMed and archived on PubMed Central

- yours - you keep the copyright
BioMedcentral 